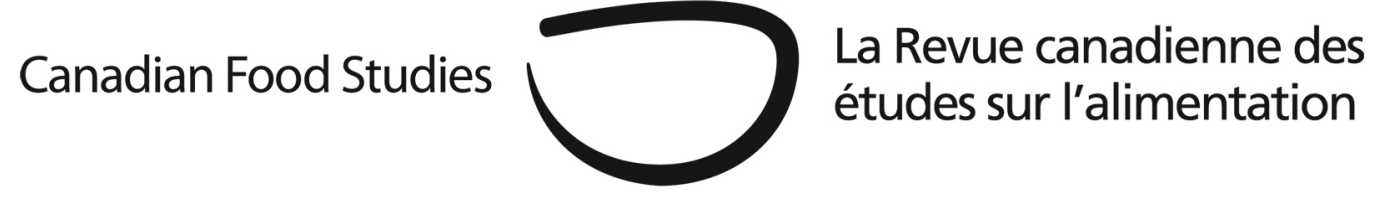

Section III

Global Food Trade

Special Issue: Mapping the Global Food Landscape

\title{
Regulating food-based agrofuels: The prospects and challenges of international trade rules
}

\author{
Matias E. Margulis \\ Lecturer in Political Economy, University of Stirling and Adjunct Professor in International Studies, \\ University of Northern British Columbia
}

This article considers the potential for strategic and selective use of World Trade Organization (WTO) rules to regulate, and potentially curb, the expansion of food-based agrofuels. Since 2008, a global agrofuel complex has emerged that is characterized by government-led mandates and investment for food-based agrofuel production and trade. The majority of world agrofuel production utilizes basic foodstuffs-sugar, corn/maize, soy and palm oil-thus generating competition between food/feed and fuel end-uses. This competition is strongly linked to food price volatility, food insecurity and land grabbing on a global-scale. Food-based agrofuel production is projected to increase significantly over the next decade, with international trade of agrofuels growing in tandem due to rising global demand. Despite well-documented social and ecological consequences associated with food-based agrofuels, producing and consuming states demonstrate a lack of political will to curb future agrofuel expansion and, in particular, continue to resist demands by global civil society and other social groups for global agrofuels regulation. In a global political economic context best characterized by a global governance gap for agrofuels, I consider the prospects and challenges of strategic and selective application of WTO rules to regulate food-based agrofuels. Also considered is the legitimacy and efficacy of the WTO to fill the existing global governance gap for agrofuels, and the potential of alternative global governance institutions to play this role. 
The rise of the global food-based agrofuels complex

In the past decade, food-based agrofuels have rapidly come to form a new and significant part of the global food system (Borras, McMichael, \& Scoones, 2010). A distinguishing feature of the incipient global agrofuels complex is that its emergence is a direct result of government-led policies to support the production of alternative energy. Food-based agrofuels have quickly come to represent a growing and significant proportion of world agricultural production, increasing six fold between 2002 and 2012 (OECD-FAO, 2012; see Table 1). Agrofuels are increasingly intertwined with global food trade, as a number of major consuming countries are importing food stocks as inputs to meet demand for "green" transport fuels.

An analytical distinction is made in this article between food-based agrofuels and other types of agrofuels. Food-based agrofuels (also referred to as "first-generation" agrofuels) are produced with the input of staple food products such as maize and sugarcane, which are primarily used for bioethanol, and soy, palm, and other vegetable oils used for biodiesel. Nonfood based agrofuels involve a greater variety of plants and sources of cellulose (i.e., algae, lichens, etc.) and waste from traditional agricultural crops such as corn husks and stalks. Efforts to expand non-food based agrofuels on an industrial scale have been unsuccessful due to the lower production and distribution costs of food-based agrofuels (Carriquiry, Du, \& Timilsina, 2011). At present food-based agrofuels dominate global production and account for 80 percent and 75 percent of world bioethanol and biodiesel production, respectively (OECD-FAO, 2012, p. 84-86).

Table 1: Agrofuel production, 1980-2011

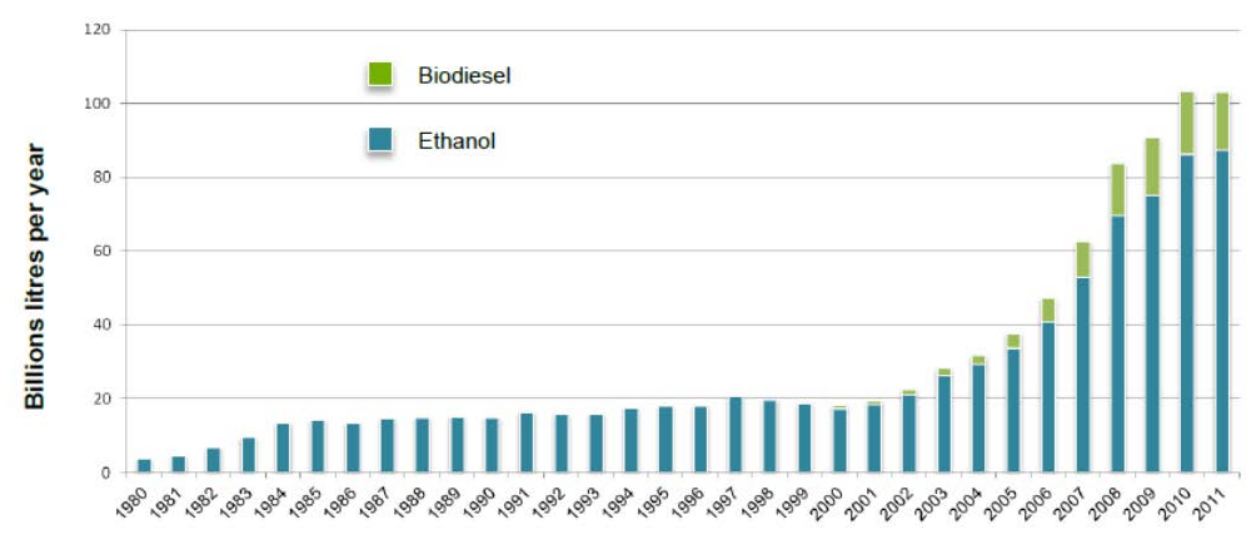

Source: HLPE (2012)

As a result, global agrofuels production generates a food (and feed) vs. fuel scenario where an increasing proportion of world agricultural production is destined for the energy sector. This development has major consequences; rising and volatile food prices and tighter world grain trade and markets are making accessibility of basic food staples a preeminent concern for low- 
income, food-importing developing countries (see Murphy, this issue). Indeed, agrofuels have heightened geopolitical tensions on the competing goals of bio-energy and food security with a new fault line drawn between food exporting and food-importing states (Margulis, 2014).

Despite repeated promises of a technological revolution for sustainable non-food agrofuels on the horizon, projections point to the opposite. World agrofuel production is expected to increase by 50 percent between 2014 and 2023 and food-based agrofuels will continue to be the main inputs for production with 12, 28 and 14 percent of world coarse grains, sugar cane, and vegetable oil production, respectively, feeding global energy demand (OECDFAO, 2012).

How did we get here? Recall that the emergence of a global agrofuel complex was advanced by Northern policymakers promoting the powerful discourse of a sustainable energy sector and energy independence (i.e., from Middle East crude oil). Also influential was private sector support driven by projected rents from "green” subsidies and profit opportunities associated with demand for new technologies, services and investment in the agrifood and energy sectors (Borras et al., 2010).

The case for food-based agrofuels has come under greater scrutiny in recent years. Scientific research has demonstrated that food-based agrofuels, which are produced through energy intensive industrial agriculture, generate a significant carbon footprint and are far less green than initially touted (Hammond \& Seth, 2013). While recognizing that the term "sustainable” is contested, food-based agrofuels are land, water and energy intensive and reproduce environmental consequences associated with mono-crop agriculture (HLPE, 2013). The idea of energy independence is illusory with nearly all agrofuel consuming countries dependent on the importation of large volumes of agrofuel feedstocks; indeed, this aspect is driving significant future growth in agrofuels trade (OECD-FAO, 2012). Agrofuels trade is now part and parcel of globally integrated production chains and trade networks (Dauvergne \& Neville, 2009). For example, Brazil and the U.S. trade significant amounts of feedstocks and refined food-based agrofuels with one another. More recently, other middle-income developing countries (e.g., Pakistan, Indonesia and Costa Rica) are restructuring agricultural systems for food-based agrofuels exports often in the name of rural economic "development” (Dufey, 2006; McMichael, 2010). As a result of these trends, agrofuels are producing new international relations of energy dependence as state-driven mandates rub up against both natural and marketbased constraints on domestic production.

The global governance gap for food-based agrofuels

A key challenge is resolving the global governance gap for food-based agrofuels. Despite comprehensive evidence that links food-based agrofuels with food insecurity, land grabbing and ecological degradation, there are no yet agreed upon international norms and rules to regulate food-based biofuels (Lima \& Gupta, 2013; see Hunsberger, this issue). That is not to say there 
have not been acknowledgements by states of the need for international rules. In the 2008 Leaders Statement on Global Food Security, the Group of Eight (G8) called for international cooperation to "ensure the compatibility of policies for the sustainable production and use of biofuels with food security and accelerate development and commercialization of sustainable second-generation biofuels from non-food plant materials and inedible biomass; in this regard, we will work together with other relevant stakeholders to develop science-based benchmarks and indicators for biofuel production and use” (G8, 2008). Yet the G8's own call for evidence-based standards to develop global regulation faltered. The reasons for this are not fully clear, however it is likely that Northern lobbying in favour of agrofuel mandates played a role. Also, disagreement among the G8 and emerging powers such as Brazil (a major agrofuel exporter and consumer) and China (a major agrofuel importer and consumer) over the necessity and desirability of international regulation of agrofuels diminished momentum for action.

Other global efforts to regulate and/or rollback food-based agrofuels have been unsuccessful. For example, in 2007 the former United Nations Special Rapporteur on the right to food, Jean Ziegler, called for a five-year moratorium on food-based agrofuels until it could be demonstrated they did not pose a threat to world food supplies. This proposal had no international take-up. In 2008, the U.K. parliament recommended a moratorium on food-based agro-fuels without success. More recently, the European Union (EU) proposed to reform its agrofuels mandate in response to concerns its policies were driving deforestation in developing countries. Under consideration is a proposal to cap food-based agrofuels to a maximum of 7 percent of all energy used for transport fuel, however, there is uncertainty about whether a sufficient number of EU members will vote in support of this reform.

Regulating agrofuels at the international level: The promise and pitfalls of trade rules

The current situation appears to be one of an absence of national and international political will to address the governance gap for food-based agrofuels. This is a significant problem because whereas food-based agrofuels are driven by domestic (i.e., national) policy, they constitute a global scale challenge due to the complex, cross-border linkages of production and consumption with food security and the environment (German, Schoneveld, \& Pacheco, 2007).

Global policy debates vary on the best way forward to regulate agrofuels. Northern states and industry argue that multistakeholder regimes (Bailis \& Baka, 2011), such as the roundtables for responsible soy and palm oil that allow for third-party certification of environmental and social standards (Ponte, 2014), are promising. However, the literature questions the efficacy of these hybrid approaches. Hunsberger, Bolwig, Corbera, \& Creutzig (2014) note that such schemes insufficiently address governance concerns about the social and ecological impacts of agrofuels. In addition, these schemes lack binding enforcement and have a mixed record of success (Fortin \& Richardson, 2013; Mol, 2010). More importantly, such self-governing regimes do not fundamentally challenge the logic of national food-based agrofuel policies but, instead, 
seek to increase their "sustainability” by providing producers and traders with credibility and access to markets. The limitations of certification in this context are illustrated by private certifiers targeting producers, and not the national mandates that undergird the emerging global agrofuels complex.

Another approach would be establishing new supranational and enforceable regulation targeted at states' agrofuel mandates. This is arguably a highly desirable course of action to address the global governance gap. However, the failed calls for a moratorium, and the lack of G8 follow through, suggests that unfavourable conditions remain for new enforceable international rules negotiated by states. Therefore, a pragmatic alternative may be to consider if and how existing international rules could be applied strategically and/or selectively to regulate food-based agrofuels.

I now turn to consider the strategic and selective use of existing WTO trade rules to regulate food-based agrofuels. To some readers, the idea of using WTO rules to regulate foodbased agrofuels will be highly controversial. This idea will be ferociously rejected by both free trade ideologues that balk at the idea of "misusing” WTO rules and by food sovereigntists for whom the WTO is anathema (see Burnett \& Murphy, 2014; Desmarais, 2007). However, given the global governance gap for food-based agrofuels and the desirability for enforceable regulation in the here and now, there are several reasons for a serious debate about the promise and pitfalls of WTO rules. I do not claim that WTO rules are "the solution" to regulating foodbased agrofuels, but as I will illustrate below, they provide a pre-existing set of enforceable rules that could be used strategically and selectively to curb, and potentially roll-back, food-based agrofuels.

Why consider WTO trade rules for regulating food-based agrofuels? There are several reasons for this. First, it is firmly established that WTO rules already apply to the production, trade and use of food-based agrofuels. Many (if not most) of the policy instruments that make national agrofuel mandates possible-direct subsidies, taxes, state financing, local-content provisions, public research and development, tariffs, and so on-are subject to existing WTO trade rules (Harmer, 2009). This means that, in practice, the WTO already has the governing authority, without the need of additional regulatory powers, to regulate agrofuels. No other set of existing international rules can be applied in an equally direct fashion to food-based agrofuels.

Second, food-based agrofuels are already an issue of significant political discord at the WTO. Many states have launched, resolved, and/or are initiating trade disputes over agrofuels at the WTO's dispute settlement system (i.e., its international trade court). Prominent trade disputes include U.S.-Brazil on ethanol (2008), U.S.-Costa Rica on dehydrated ethanol (2013), European Union (EU)-U.S. on anti-dumping of ethanol (2012), and Argentina-EU on imports of biodiesel (2013). In other words, efforts to strategically and selectively use international trade rules to curb the production and trade of agrofuels is already taking place at the WTO. In particular, the flurry of agrofuels trade disputes is highly significant to debates about regulating agrofuels because these cases are making the WTO a source of: 1) globally-enforced changes to states' agrofuel mandates and policies; and, 2) international legal jurisprudence for agrofuels. As a result, the 
applicability of its trade rules and its enforceable decisions has already de facto provided globalscale regulatory authority for agrofuels to the WTO. In other words, the WTO is already filling the global governance gap for food-based agrofuels. Whether particular outcomes of WTO decisions on food-based agrofuels are desirable is up for debate and merits further discussion (for example, see Hunsberger in this issue on the WTO chilling effect on demand for labour and social standards in agrofuels supply chains). However, the larger point for the purpose of this article is that supranational regulation of agrofuels is currently taking place and this is occurring at the WTO.

Third, no other international treaty or institution has the capacity and international legal authority to regulate national agrofuel policies. I rule out soft law approaches in general. Although the need for normative guidance remains crucial, soft law is unenforceable and does little to address the problems of agrofuels right now. It is well known that United Nations (UN) environmental treaties lack enforceability, and have not produced rules as specific as the WTO's in relation food-based agrofuels. Moreover, it is unclear if the UN climate change regime is an ideal place to address agrofuels-related concerns given the debate as to whether schemes such as the Reducing Emissions from Deforestation and Forest Degradation (REDD), which provides developing countries financial incentives to conserve forests, may be legitimating the expansion of palm oil plantations for agrofuel production at the expense of biodiversity. The UN Committee on World Food Security (CFS) has successfully demonstrated its capacity to advance policy debate and rule-making for global food-security governance, including debates on agrofuels, and enjoys a high level of legitimacy due to its multistakeholder representation (see McKeon and Duncan, this issue). However, simply put, the CFS does not have the regulatory powers to enforce international law and target state-mandated agrofuels. Other global institutions such as the International Energy Agency (IEA) reflect the preferences of a small group of global North countries, most of which are producers and consumers of food-based agrofuels and are, therefore, unlikely to provide satisfactory solutions.

WTO trade law is a highly technical subject, and given the brevity of this article, I will only sketch out some ways in which WTO trade rules could be strategically and selectively used to regulate food-based agrofuels.

One point of entry is the WTO's Agreement on Agriculture that limits the total value of subsidies and other support measures states can provide to their agricultural sector. At present, subsidies for food-based agrofuels have not been counted at the WTO as part of states' agricultural support spending. Yet the production and economic viability of food-based agrofuels are made possible to a large extent by government subsidies and other forms of what, under WTO rules, plausibly qualify as state-funded “agricultural support”. WTO rules enforce strict limits on how much states can spend, and a shift to including agrofuel-related spending into the accounting of total agricultural spending at the WTO would find agrofuel producing states in a position of reporting much higher levels of agricultural support. 
Such accounting could have two interrelated effects. First, given that the main agrofuel producing states regularly spend at high levels of allowable support, accounting for food-based agrofuels spending may result in these countries surpassing their WTO spending limits and thus be in violation of international law, making them vulnerable to trade disputes and costly retaliation (i.e., sanctions). This is indeed a plausible scenario because WTO rules work in a manner to limit, in particular, how much subsidy and other forms of agricultural support a single crop can receive (this is known as "crop-specific support”). Given that food-based agrofuels essentially rely on roughly three crops for all production it may well be the case that many agrofuel-producing states would find themselves close to or offside WTO rules on a cropspecific basis of accounting. This would be a high-risk scenario for states and would put them under international pressure to lower levels of support to food-based agrofuels.

Second, accounting for food-based agrofuels as a form of support at the WTO would lead to greater internal political discord within producing states. Government agricultural spending, due to the binding WTO limits, is a zero-sum game played among competing domestic interest groups and political actors. If accounting for agrofuels forces governments to reduce their level of spending, it is logical to expect that a shrinking overall pie would pit domestic interest groups (and their political counterparts) in an intensified competition for a limited pool of state resources. Given the significant political influence of domestic agricultural lobbies in most agrofuel producing states, and taking into consideration the sometimes competing interests of agricultural and agrofuel producers, a shrinking pie could push many agricultural producers, traders and retailers that do not benefit from agrofuels to support diminishing levels of government support for food-based agrofuels, even plausibly creating greater incentives for nonfood based agrofuels or other forms of renewables.

Other areas of WTO trade law that are relevant to consider for regulating food-based agrofuels include domestic content rules and research and development subsidies. It is unlikely that a silver bullet is to be found in the WTO, but the coordinated, strategic, and selective use of multiple WTO rules offers one proven means to curb food-based agrofuels in the here and now. Such a route does not require the creation of new global regulation for food-based agrofuels. The context is important as the WTO faces an internal crisis of legitimacy. The repeated breakdown of the Doha Round negotiations illustrates fractured relations among WTO member states, especially the old and new powers (Hopewell, 2014), due to competing visions of how the international trading system should operate. The uncertainty over the future of the WTO and the breakdown of the old power structure creates a window of opportunity.

Whether the strategic and selective use of WTO rules is desirable and feasible in practice requires further research and debate. This will require communication, consultation and collaboration not just among academics and civil society, but also with national government representatives to the WTO. For even if a solid case, based on research, could be made to use WTO rules to regulate food-based agrofuels, a WTO member state is required to champion the issue because the institution operates exclusively as an inter-state forum. Unlike the CFS, academic and global civil society voices do not go far at the WTO. Therefore, a successful 
approach would require a transnational advocacy campaign to bring attention to the issue and shape public opinion, while also working with sympathetic WTO member states to put pressure on other governments. Precedent exists for this, such as the alliance between NGOs and developing countries on the waiver for HIV/AIDs medicines from the WTO's intellectual property trade rules (He \& Murphy, 2007).

Any effort to steer states towards changes in global governance is rather long and must navigate complex political terrains at various scales. However, there are reasons why the strategic and selective use of WTO rules could have support. Consider that the majority of the WTO’s 160 member states are net-food importers and have already publicly criticized foodbased agrofuels mandates for increasing food insecurity. This suggests a potentially large and sympathetic constituency (see Murphy, this issue). In addition, the advocacy strategy of vilifying (certain) agricultural subsidies at the WTO has proved successful in the past for fostering coalitions among states, academics and global civil society, and has resulted in concrete changes to state practices (i.e., vilifying U.S. cotton subsidies that impoverish African cotton farmers). The recent success of India, garnering support for its national food stockholding scheme, is an important example of the new political dynamics of the food-security debate at the WTO (Kripke, this issue); more importantly, the India case provides an important lesson regarding the viability of creative interpretation of WTO rules and moral suasion in the name of food security.

To conclude, in the context of widespread recognition of the pressing need to curtail the harmful social and ecological consequences of food-based agrofuels, and as long as governments remain unwilling to create new global enforceable regulation, the strategic and selective use of WTO rules to regulate food-based agrofuels is an idea that merits future research and debate among academics, activists and policymakers. Some promising areas for future research would be a scoping study of WTO rules and dispute panel decisions to identify which areas of international trade law apply to the production, distribution and trade of agrofuels. Similarly, a detailed assessment of past and current global policy statements and proposals to regulate agrofuels would help to identify and compare the range of possible modalities. More importantly, a mechanism to foster open dialogue among trade experts, social movements and policymakers to assess the possibility of utilizing trade rules to regulate food-based agrofuels (for example, a policy workshop under the aegis of the CFS or UNFCC), should also be explored.

\section{References}

Bailis, R., \& Baka, J. (2011). Constructing sustainable biofuels: Governance of the emerging biofuel economy. Annals of the Association of American Geographers, 101(4), 827-838. 
Borras Jr, S. M., McMichael, P., \& Scoones, I. (2010). The politics of biofuels, land and agrarian change: Editors’ introduction. Journal of Peasant Studies, 37(4), 575-592.

Burnett, K., \& Murphy, S. (2014). What place for international trade in food sovereignty? Journal of Peasant Studies, 41(6), 1065-1084.

Carriquiry, M. A., Du, X., \& Timilsina, G. R. (2011). Second generation biofuels: Economics and policies. Energy Policy, 39(7), 4222-4234.

Dauvergne, P., \& Neville, K. J. (2009). The changing North-South and South-South political economy of biofuels. Third World Quarterly, 30(6), 1087-1102.

Desmarais, A. A. (2007). La Vía Campesina: Globalization and the power of peasants. Fernwood Publishing and Pluto Press: Halifax and London.

Dufey, A. (2006). Biofuels production, trade and sustainable development: Emerging issues (No. 2). IIED, London.

Fortin, E., \& Richardson, B. (2013). Certification schemes and the governance of land: Enforcing standards or enabling scrutiny? Globalizations, 10(1), 141-159.

German, L., Schoneveld, G. C., \& Pacheco, P. (2011). Local social and environmental impacts of biofuels: Global comparative assessment and implications for governance. Ecology and Society, 16(4), 29.

Group of Eight (G8). (2008). G8 leaders statement on global food security. Retrieved from www.mofa.go.jp/policy/economy/summit/2008/doc/doc080709_04_en.html

Hammond, G. P., \& Seth, S. M. (2013). Carbon and environmental footprinting of global agrofuel production. Applied Energy, 112, 547-559.

Harmer, T. (2009). Biofuels subsidies and the law of the WTO. Geneva: ICTSD.

He, B., \& Murphy, H. (2007). Global social justice at the WTO? The role of NGOs in constructing global social contracts. International Affairs, 83(4), 707-727.

High Level Panel of Experts (HLPE). (2013). Biofuels and food security. A report by the High Level Panel of Experts on Food Security and Nutrition of the Committee on World Food Security. Rome: Committee on World Food Security. 
HLPE. (2012). Food Security and Climate Change. A report by the High Level Panel of Experts on Food Security and Nutrition of the Committee on World Food Security. Rome: Committee on World Food Security.

Hopewell, K. (2014). Different paths to power: The rise of Brazil, India and China at the World Trade Organization. Review of International Political Economy, 22(2), 311-338.

Hunsberger, C., Bolwig, S., Corbera, E., \& Creutzig, F. (2014). Livelihood impacts of biofuel crop production: Implications for governance. Geoforum, 54, 248-260.

Lima, M. G. B., \& Gupta, J. (2013). The policy context of biofuels: A case of non-governance at the global level? Global Environmental Politics, 13(2), 46-64.

Margulis, M. E. (2014). Trading out of the global food crisis? The World Trade Organization and the geopolitics of food security. Geopolitics, 19(2), 322-350.

McMichael, P. D. (2010). Agrofuels in the food regime. Journal of Peasant Studies, 37(4), 609-629.

Mol, A. P. J. (2010). Environmental authorities and biofuel controversies. Environmental Politics, 19(1), 61-79.

OECD-FAO (2012). Agricultural Outlook 2011-2020. Paris: OECD.

Ponte, S. (2014). 'Roundtabling' sustainability: Lessons from the biofuel industry. Geoforum, 54, 261-271. 